\title{
Geographic variation of the large-eared field mouse (Apodemus latronum Thomas, 1911) (Rodentia: Muridae) with one new subspecies description verified via cranial morphometric variables and pelage characteristics
}

Song $\mathrm{Li}^{1,2^{*}}$ and Shao-Ying $\mathrm{Liu}^{3}$

\begin{abstract}
Background: The large-eared field mouse (Apodemus latronum Thomas, 1911), a common rodent, mainly inhabits southwestern China. Since its first description nearly a century ago, there have been numerous taxonomical and morphological arguments as to its validity, but relatively little work was done on mapping out the geographic variations observed in samples of the species. In this study, we used 142 specimens of A. latronum from Xizang, Sichuan, and Yunnan to conduct a multivariate analysis, coefficient of difference (CD) analysis of cranial measurements, and a comparison of some pelage characteristics.

Results: The results of the analysis on 15 measurable cranial characters indicated that the specimens from Lijiang, Weixi, and Binchuan areas of the Yunnan province are apparently different from all the other specimens of A. latronum described so far and are allopatrically distributed.

Conclusions: These samples form the core of our new description for A. latronum lijiangensis subsp. nov. as a new subspecies, and a detailed discussion on the relationships between the differentiation of A. latronum and its evolvement in southwestern China is provided.
\end{abstract}

Keywords: New subspecies; Geographic variation; Statistic analysis; Apodemus latronum; Morphometry

\section{Background}

The large-eared field mouse (Apodemus latronum Thomas, 1911) mainly inhabits southwestern China, including both Sichuan and Yunnan provinces as well as southeastern Tibet and northern Burma (Corbet and Hill 1992; Musser and Carleton 2005). The species was first named Apodemus speciosus latronum (Thomas 1911) based on an adult male specimen from Tatsienlu, Szechwan (modern-day Kangding, Sichuan province), and due to its large body size and big blackish ears, Osgood (1932) recognized

\footnotetext{
* Correspondence: lis@mail.kiz.ac.cn

${ }^{1}$ Kunming Natural History Museum of Zoology, Kunming Institute of Zoology, Chinese Academy of Sciences, 32 Jiaochang Donglu, Kunming, Yunnan 650223, China

${ }^{2}$ State Key Laboratory of Genetic Resources and Evolution, Kunming Institute of Zoology, Chinese Academy of Sciences, Kunming, Yunnan 650223, China Full list of author information is available at the end of the article
}

it as a species that might have been related to A. flavicollis (Melchior, 1834), and Allen (1940) also accepted the naming as $A$. latronum in subgenus Sylvaemus. Ellerman (1941), however, thought it should be A. speciosus latronum in the speciosus group of Apodemus, and later, Ellerman and Morrison-Scott (1950) regarded it as A. flavicollis latronum. Zimmermann (1962) then identified it as a valid species, and Corbet (1978) accepted this result. Nearly a decade later, Feng et al. (1986) rearranged it as A. draco latronum, followed by arguments from Corbet and Hill (1992) and Musser and Carleton (1993), all of whom insisted on the earlier result of Zimmermann (1962). This finding was later supported by Huang et al. (1995) and Musser et al. (1996) who went on to expatiate on the validity of $A$. latronum with morphological or published genetic evidence (Suzuki et al. 2003). Finally, both 
Wang (2003) and Musser and Carleton (2005) listed it as A. latronum.

After so many arguments on its taxonomic status and the subsequent genetic studies to clarify any inconsistencies, there has been no recent disagreement as to the status of A. latronum as a valid species. Interestingly though, there have been no further follow-up morphological studies conducted to obtain a more well-rounded view of this species, especially in regard to measureable cranial variables or comparisons of pelage characteristics as it pertains to the geographic variation of A. latronum. In this study, we opted to conduct a typical morphometric analysis of both morphometrics and related statistical analyses on the skull of $A$. latronum, and comparison on their pelage characteristics is performed in order to study their geographic variation. Additionally, we also discussed the relationships between the differentiation of A. latronum and its environment in southwestern China.

\section{Methods}

\section{Data collection}

The specimens used in the study were obtained from Kunming Natural History Museum of Zoology, Kunming Institute of Zoology, Chinese Academy of Sciences (KIZ, CAS) (Kunming, China), Institute of Zoology, Chinese Academy of Sciences (IOZ, CAS) (Beijing, China), and Sichuan Academy of Forestry (SAF) (Chengdu, China). The numbers and collection localities of specimens examined in the study are listed in detail in the Appendix.
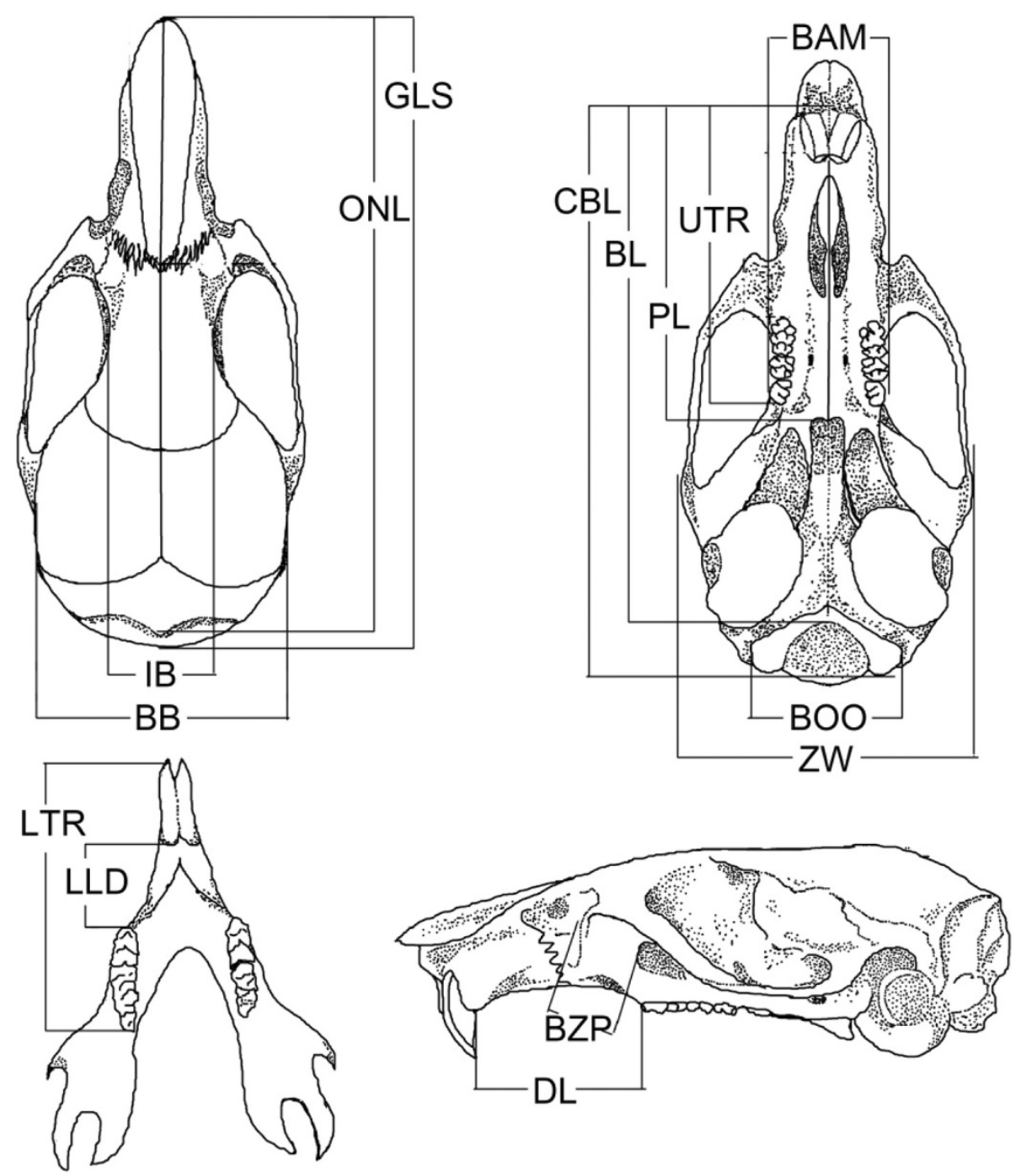

Figure 1 Sketch map indicating 15 cranial measurements in the study. GLS, greatest length of skull; CBL, condylobasal length; BL, basal length; ONL, occipitonasal length; PL, palatal length; DL, diastema length; UTR, upper tooth row; BAM, breadth across molars; BZP, breadth of zygomatic plate; BOO, breadth of occipital condyles; ZW, zygomatic width; IB, interorbital breadth; BB, breadth of braincase; LLD, length of lower diastema; LTR, lower tooth row. 
A total of 142 specimens were studied. Excluding four specimens that have no noted sexual record, the remaining 138 specimens include 64 male samples and 74 female samples. All specimens used in this study are considered to have been adults at the time of their collection, because it was evident from examination that molar eruption had finished, and the grinding surface of $\mathrm{M}^{2}$ appears as a longitudinal worn dentine link ( $\mathrm{Lu}$ et al. 1987). Totally, 15 cranial measurements were taken with a digital caliper at the greatest possible accuracy $(0.01 \mathrm{~mm})$ as follows: greatest length of skull (GLS), condylobasal length $(\mathrm{CBL})$, basal length (BL), occipitonasal length (ONL), palatal length (PL), diastema length (DL), upper tooth row (UTR), breadth across molars (BAM), breadth of zygomatic plate (BZP), breadth of occipital condyles (BOO), zygomatic width $(\mathrm{ZW})$, interorbital breadth (IB), breadth of braincase (BB), length of lower diastema (LLD), and lower tooth row (LTR) (Figure 1). In addition, four external measurements were taken from the initial accession labels attached to the skin: head and body length (HB), tail length (TL), hind foot length (HFL), and ear length (EL). Since these measurements were taken by a variety of different collectors who likely used different tools and methodologies, these four metrics were not included either in the multivariate or coefficient of difference (CD) analyses.

\section{Data analysis}

Following the aforementioned data collection, the 15 cranial measurements we took were log-transformed and analyzed for sexual dimorphism (for the 138 samples with known sex records). After which, principal component analyses (PCA) without assuming a prior group was used to identify the various groupings of the samples. The groups identified via PCA were then assigned with names; then, multiple comparisons between the groups were performed for all 15 cranial variables, and the coefficient of difference analysis (CD) (Mayr 1969) between the groups was calculated using the following equation: $\mathrm{CD}=(\mathrm{Mb}-M \mathrm{a}) /$ $(\mathrm{SDa}+\mathrm{SDb})$, where $M \mathrm{~b}$ is the mean of population $\mathrm{b}, \mathrm{Ma}$ is the mean of population a, SDa is the standard deviation of population $\mathrm{a}$, and $\mathrm{SDb}$ is the standard deviation of population $b$. The principal component analyses and multiple comparisons were performed using SPSS version 11.0 (SPSS Inc., Chicago, IL, USA).

\section{Pelage comparisons}

Pelage characteristics are well known to change during different seasons, and as such, it can be difficult to make comparisons between samples taken at different times of the year. In order to eliminate the influence of seasonal pelage characteristic variation, we selected samples with the same collection date of topotype of $A$. latronum latronum and the type of $A$. latronum lijiangensis to compare the pelage characteristics.
Table 1 Tests of equality of group means by gender

\begin{tabular}{lccccc}
\hline Variables & Wilks' Lambda & $\boldsymbol{F}$ & d.f. $\mathbf{1}$ & $\boldsymbol{d} . \mathbf{f} . \mathbf{2}$ & $\boldsymbol{p}$ \\
\hline GLS & 0.961 & 5.543 & 1 & 135 & $0.020^{*}$ \\
CBL & 0.959 & 5.825 & 1 & 135 & $0.017^{*}$ \\
BL & 0.963 & 5.168 & 1 & 135 & $0.025^{*}$ \\
ONL & 0.976 & 3.352 & 1 & 135 & 0.069 \\
PL & 0.970 & 4.212 & 1 & 135 & $0.042^{*}$ \\
DL & 0.974 & 3.653 & 1 & 135 & 0.058 \\
UTR & 0.966 & 4.793 & 1 & 135 & $0.030^{*}$ \\
BAM & 0.998 & 0.244 & 1 & 135 & 0.622 \\
BZP & 1.000 & 0.003 & 1 & 135 & 0.954 \\
BOO & 0.964 & 5.037 & 1 & 135 & $0.026^{*}$ \\
ZW & 0.979 & 2.834 & 1 & 135 & 0.095 \\
IB & 0.993 & 1.009 & 1 & 135 & 0.317 \\
BB & 0.969 & 4.358 & 1 & 135 & $0.039^{*}$ \\
LLD & 0.998 & 0.294 & 1 & 135 & 0.589 \\
LTR & 0.950 & 7.101 & 1 & 135 & $0.009^{*}$ \\
\hline
\end{tabular}

The variable codes are given in the text and in Figure 1. Asterisk means significant difference.

Table 2 Factor loadings and percentage of variance explained for principal component analysis on A. Iatronum male samples

\begin{tabular}{lccc}
\hline Variables & \multicolumn{3}{c}{ Principal component (PC) } \\
\cline { 2 - 4 } & $\mathbf{1}$ & $\mathbf{2}$ & $\mathbf{3}$ \\
\hline GLS & 0.907 & 0.303 & 0.168 \\
CBL & 0.924 & 0.260 & 0.190 \\
BL & 0.929 & 0.225 & 0.193 \\
ONL & 0.914 & 0.244 & 0.171 \\
PL & 0.866 & 0.345 & 0.228 \\
DL & 0.899 & 0.233 & 0.237 \\
UTR & 0.889 & 0.345 & 0.221 \\
BAM & 0.662 & 0.458 & 0.185 \\
BZP & 0.734 & 0.367 & -0.307 \\
BOO & 0.276 & 0.643 & 0.218 \\
ZW & 0.749 & 0.487 & 0.179 \\
IB & 0.156 & 0.783 & -0.133 \\
BB & 0.343 & 0.766 & 0.151 \\
LLD & 0.258 & 0.006 & 0.853 \\
LTR & 0.710 & 0.216 & 0.461 \\
Eigenvalues & 10.24 & 1.23 & 0.86 \\
Variance explained (\%) & 68.26 & 8.21 & 5.76 \\
\hline
\end{tabular}

The variable codes are given in the text and in Figure 1. The extraction method used is the principal component analysis. The rotation method is Varimax with Kaiser Normalization. 


\section{Results}

Sexual dimorphism and principal component analyses

Of the 142 total samples that were used for cranial measurements, 138 contained sexual information on their labels, with 64 male specimens and 74 female specimens (one without skull). The results from the Tests of Equality of Group Means indicated that 8 of the measured 15 cranial variables exhibited significant differences $(p<0.05)$ between males and females (Table 1). Since 8 out of 15 cranial variables show significant differences and some marked sexual dimorphism, we conducted principal component analyses and found that among the male group $(N=64)$, the eigenvalues for the first three principal components were $10.24,1.23$, and 0.86 , respectively, thereby accounting for $82.22 \%$ of the total variance. Most of the measured characteristics had high positive loadings on the first principal component, suggesting that this component $(68.26 \%$ of the total variance) represents size
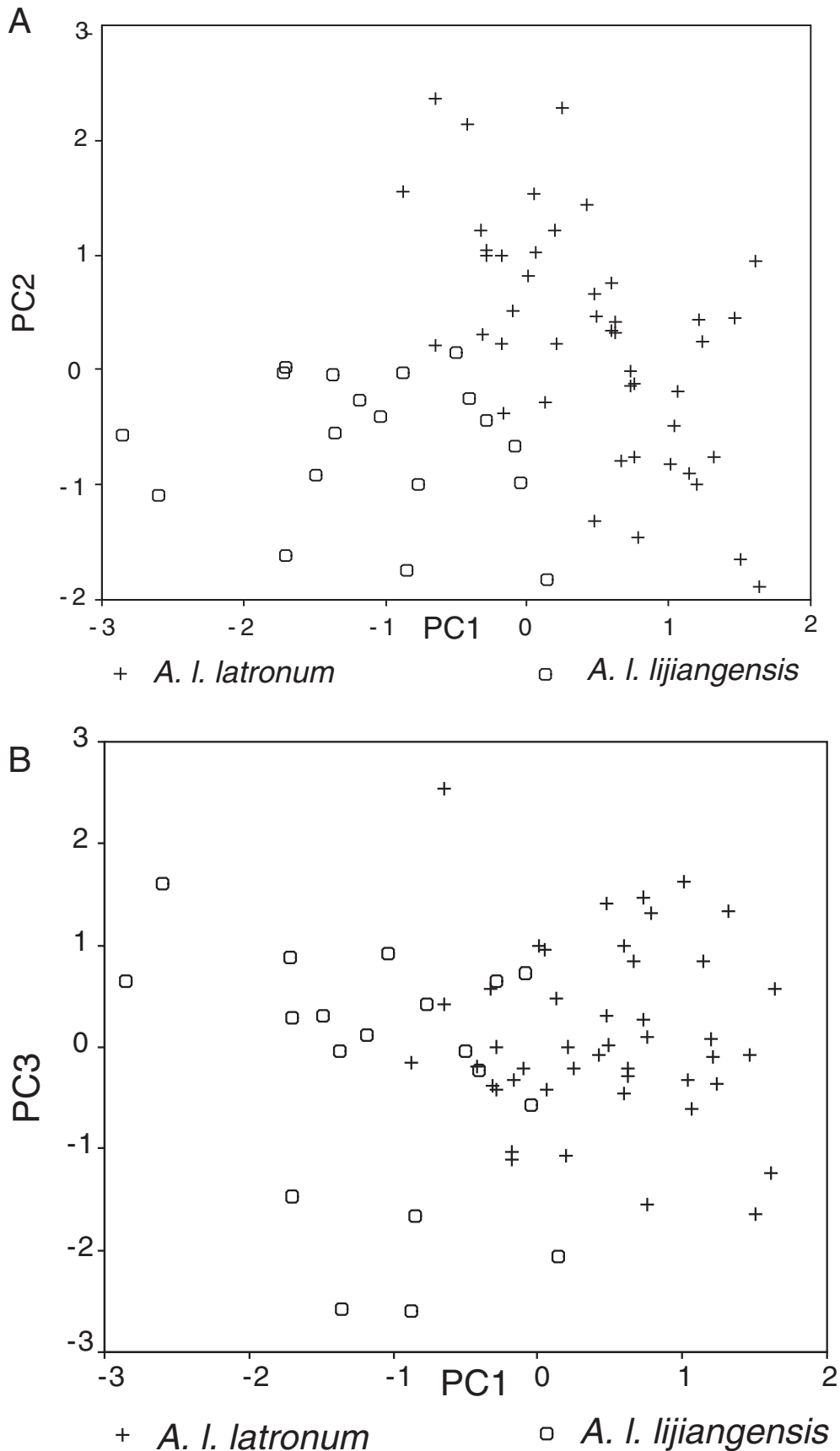

Figure 2 Regional distribution of $A$. latronum male samples by plotting on principal components factors. (A) PC1 by PC2. (B) PC1 by PC3. 
variation among the samples. The second principal component ( $8.21 \%$ of variance) was strongly correlated with $\mathrm{IB}$ and $\mathrm{BB}$ (factor loadings $>0.70$ ), while the third principal component $(5.76 \%$ of variance) is correlated primarily with LLD (factor loadings $>0.70$ ) (Table 2). Figure 2A,B shows the plots of $A$. latronum male samples on principal component factors 1 vs. 2 and 1 vs. 3 , respectively.

Similar results were found among the female group. For the 73 skull specimens in the female group, The PCA analysis showed that the eigenvalues for the first three principal components were $11.49,0.89$, and 0.67 , respectively, accounting for $86.93 \%$ of the total variance. Most characteristics had high positive loadings on the first principal component, suggesting that this component $(76.57 \%$ of the total variance) likewise represents size variation, while the second principal component (5.92\% of variance) was also strongly correlated with LLD (factor loadings $>0.70$ ); the third principal component $(4.44 \%$ of variance) was correlated primarily with IB (factor loadings > 0.70) (Table 3). Scatter plots of $A$. latronum female samples on PC1 by $\mathrm{PC} 2$ and $\mathrm{PC} 1$ by PC3 are shown in Figure 3A,B, respectively.

The collective results from both the male and female groups together (Figures 2 and 3 ) indicate that the samples

Table 3 Factor loadings and percentage of variance explained for principal component analysis on A. Iatronum female samples

\begin{tabular}{lccc}
\hline Variables & \multicolumn{3}{c}{ Principal component (PC) } \\
\cline { 2 - 4 } & $\mathbf{1}$ & $\mathbf{2}$ & $\mathbf{3}$ \\
\hline GLS & 0.792 & 0.408 & 0.396 \\
CBL & 0.792 & 0.412 & 0.409 \\
BL & 0.784 & 0.419 & 0.411 \\
ONL & 0.759 & 0.427 & 0.425 \\
PL & 0.783 & 0.410 & 0.382 \\
DL & 0.703 & 0.556 & 0.397 \\
UTR & 0.832 & 0.385 & 0.350 \\
BAM & 0.848 & 0.260 & 0.121 \\
BZP & 0.583 & 0.291 & 0.569 \\
BOO & 0.722 & 0.157 & 0.293 \\
ZW & 0.808 & 0.330 & 0.350 \\
IB & 0.170 & 0.005 & 0.931 \\
BB & 0.809 & 0.007 & 0.107 \\
LLD & 0.265 & 0.917 & 0.008 \\
LTR & 0.794 & 0.420 & 0.123 \\
Eigenvalues & 11.49 & 0.89 & 0.67 \\
Variance explained (\%) & 76.57 & 5.92 & 4.44 \\
\hline The varabe codes are & &
\end{tabular}

The variable codes are given in the text and in Figure 1. The extraction method use is the principal component analysis. The rotation method is Varimax with Kaiser Normalization. are actually composed of two different groups, and the results of multiple comparisons show significant difference between $A$. latronum latronum and A. latronum lijiangensis (Table 4); also, sustaining the samples could be distinguished into two different groups by skull variables. Paired with the data on the geographic distributions of the collection localities (Figure 4), we found that the samples from the Lijiang, Weixi, and Binchuan areas of the Yunnan province form a distinct group which we have named (A. latronum lijiangensis, subsp. nov.). The other samples from the Sichuan province (including Markam, Baoxing, Yajiang, Luhuo, Baiyu, Batang, Danba, Daocheng, and Muli areas), northwestern Yunnan province (including Xiaozhongdian and Deqin areas), and southeastern Tibet (including Mangkang, Zuogong, and Bomi areas) form the other absolute group (A. latronum latronum).

\section{Coefficient of difference analysis}

The comparisons on the $\mathrm{CD}$ for the 15 cranial measurable variables between the two distinct groups, A. latronum lijiangensis subsp. nov. and A. latronum latronum (see Table 5) showed that the CDs of GLS, ONL, DL, and UTR are larger than 1.28 between A. latronum latronum and $A$. latronum lijiangensis. External and cranial measurements of $A$. latronum latronum and $A$. latronum lijiangensis subsp. nov. are given in Table 6.

\section{Description of one new subspecies, Apodemus latronum lijiangensis Li et Liu, subsp. nov.}

Holotype: KIZ 016518, ô, adult, collected 19 October 2007, from Yulong Snow mountain, Lijiang, Yunnan Prov., China, elevation 3,305 m.

Paratype: KIZ 016549, ㅇ, adult, collected 19 October 2007, from Yulong Snow mountain, Lijiang, Yunnan Prov., China, elevation 3,305 m.

Specimens examined: $17 \hat{\jmath}, 419 q$, and one (no sexual recording) from Lijiang, Weixi, and Binchuan areas of the Yunnan province (Appendix).

Etymology: This new subspecies was named according to the type locality.

Diagnosis: General dorsal color is brown, mixed with black more or less, and from the back to the flank, it changes from fawn brown to clay brown. The muzzle and its sides are mainly grayish mixed black, while the forehead, the central area of the crown, and nape fawn brown are thinner, but largely the same as that at the back.

Description: A. latronum lijiangensis subsp. nov. exhibits several distinct and apparently fairly stable characteristics: (1) general dorsal color is brown, mixed with black more or less, and from the back center to the flank, it changes from fawn brown to clay brown, apart from A. latronum latronum, which is ochraceous or ochraceous buff, clearly; (2) underparts gray at base and tipped with dull white; (3) 


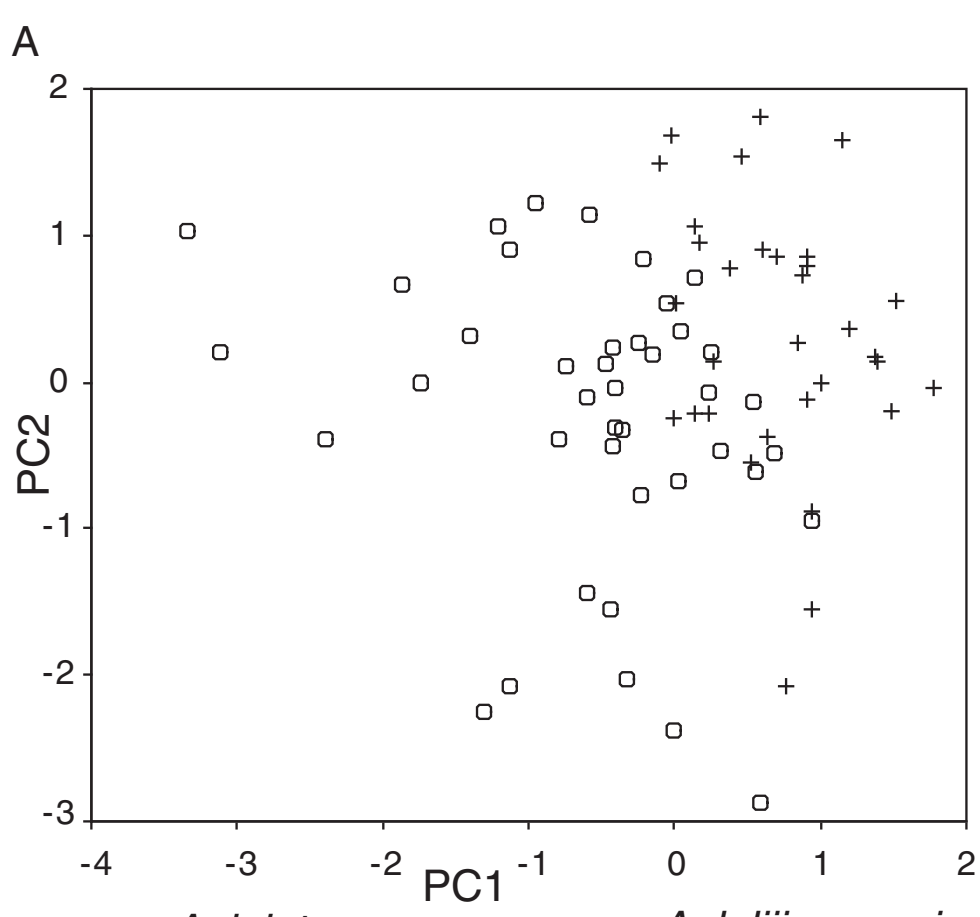

+ A. I. latronum

- A. I. lijiangensis

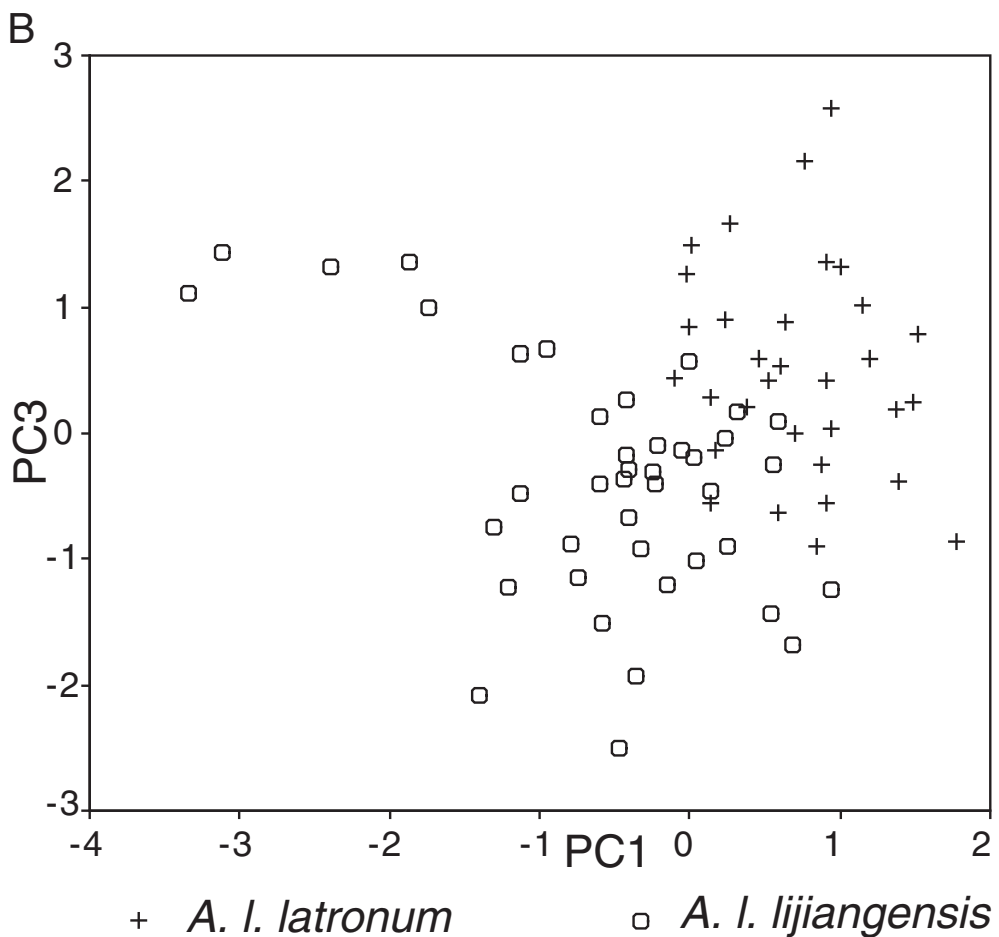

Figure 3 Regional distribution of $A$. latronum female samples by plotting on principal components factors. (A) PC1 by PC2. (B) PC1 by PC3.

the muzzle and its sides mainly grayish mixed black; the forehead, the central area of the crown, and nape fawn brown, just the same as the back, but thinner more or less; apart from $A$. latronum latronum, which the muzzle mainly black brown, and its sides mainly yellow brown;
(4) flanks and sides of cheeks and neck are clay brown; (5) orbits dark brownish; (6) the upper surfaces of the front and hind feet dull white; (7) the tail dark brown above and the undersurface brown in the base but more and more thinner to the twig, apart from A. latronum latronum, 
Table 4 Multiple comparisons on all 15 cranial variables between $A$. latronum latronum and $A$. latronum lijiangensis

\begin{tabular}{lcc}
\hline Variables & Mean difference & $\boldsymbol{p}$ \\
\hline GLS & $0.036^{*}$ & 0.000 \\
CBL & $0.037^{*}$ & 0.000 \\
BL & $0.039^{*}$ & 0.000 \\
ONL & $0.034^{*}$ & 0.000 \\
PL & $0.037^{*}$ & 0.000 \\
DL & $0.049^{*}$ & 0.000 \\
UTR & $0.037^{*}$ & 0.000 \\
BAM & $0.025^{*}$ & 0.000 \\
BZP & $0.052^{*}$ & 0.000 \\
BOO & $0.024^{*}$ & 0.000 \\
ZW & $0.027^{*}$ & 0.000 \\
IB & $0.015^{*}$ & 0.000 \\
BB & $0.013^{*}$ & 0.000 \\
LLD & $0.024^{*}$ & 0.000 \\
LTR & $0.033^{*}$ & 0.000 \\
\hline
\end{tabular}

The variable codes are given in the text and in Figure 1. Asterisk means significant difference. which the whole tail undersurface deep brown and mixed with black in its twig more or less.

Synonyms: Apodemus latronum latronum, Thomas 1911, Abstr. Proc.Zool. Soc. Lond., 100: 49.

Measurements (see Table 7 for external and skull of type specimens of $A$. latronum lijiangensis subsp. nov).

Remarks: This subspecies is known to presently dwell in Lijiang, Weixi, and Binchuan, Yunnan province, and its distribution apparently does not overlap with the other known subspecies. A. latronum latronum occurs both in Xiaozhongdian and Deqin of the Yunnan province as well as in southeastern Tibet and Sichuan province. According to the theory of subspecies differentiation (Mayr 1969), when the $C D$ of any parameter of variables within two samples exceeds 1.28 , the samples can be regarded as different subspecies. The results of $\mathrm{CD}$ analysis indicate that among these 15 variables, 4 of the 15 CDs exceeded 1.28 between $A$. latronum lijiangensis subsp. nov. and A. latronum latronum (Table 5). On the pelage characteristics, A. latronum lijiangensis subsp. nov. can clearly be distinguished from $A$. latronum latronum by the following combinations of characteristics described above: (1), (3), and (7), further confirming the validity of this

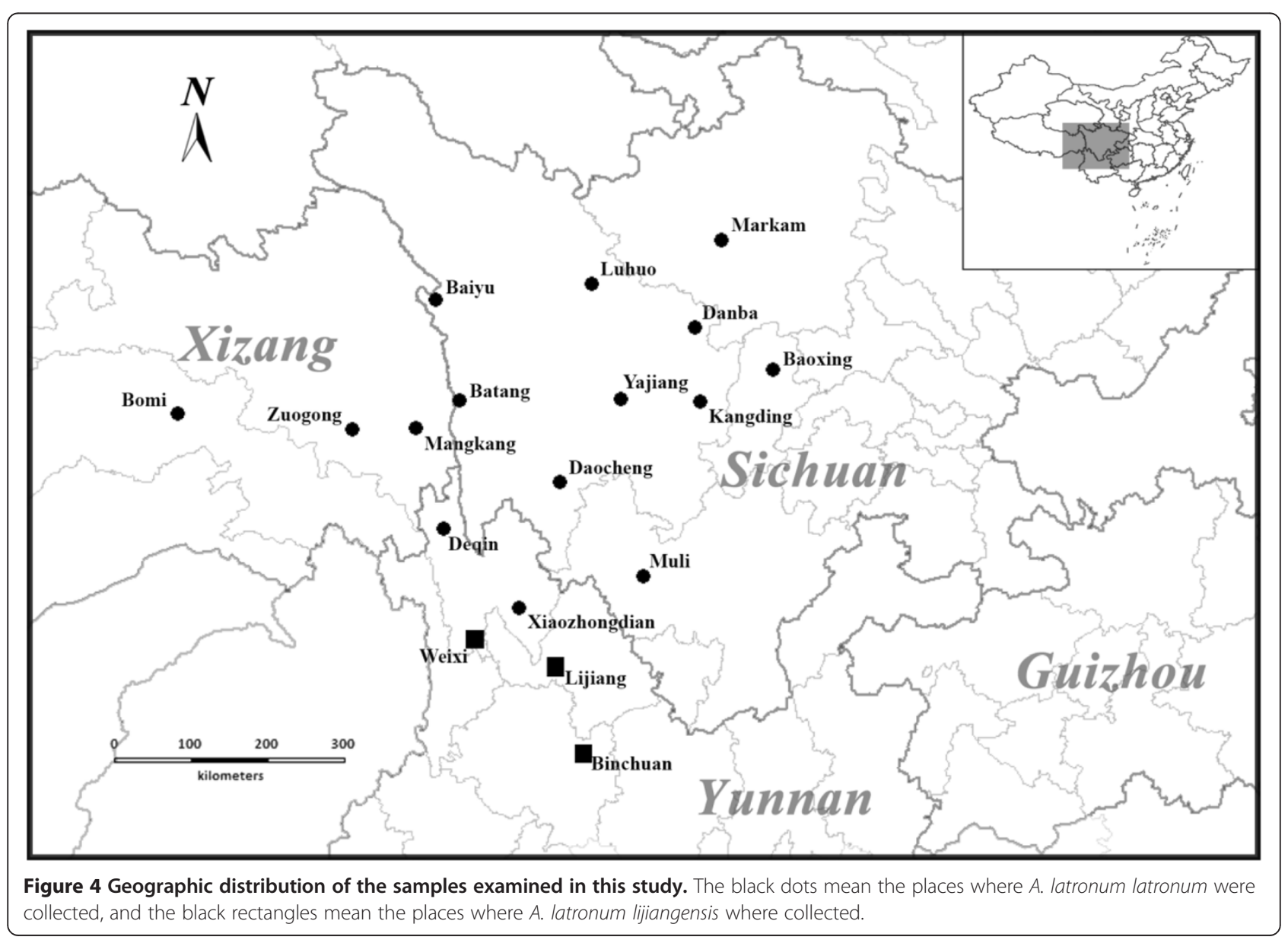


Table 5 Comparison of coefficient of difference (CD) between $A$. latronum latronum and $A$. latronum lijiangensis, subsp. nov.

\begin{tabular}{ll}
\hline Variables & CD \\
\hline GLS & 1.40 \\
CBL & 1.27 \\
BL & 1.21 \\
ONL & 1.29 \\
PL & 1.21 \\
DL & 1.29 \\
UTR & 1.41 \\
BAM & 0.85 \\
BZP & 0.88 \\
BOO & 0.94 \\
ZW & 1.04 \\
IB & 0.54 \\
BB & 0.62 \\
LLD & 0.45 \\
LTR & 1.02 \\
\hline
\end{tabular}

Italicized values denote those four measurements greater than 1.28. The variable codes are given in the text and in Figure 1. new subspecies. Figure 5 indicates the pelage differences between $A$. latronum lijiangensis and A. latronum latronum.

\section{Discussion}

A. latronum has previously been regarded as a valid species (Allen 1940; Zimmermann 1962; Corbet and Hill 1992; Musser and Carleton 1993; Musser et al. 1996; Musser and Carleton 2005), and in 2010, based on molecular data, Sakka et al. (2010) found that 'the phylogeographic pattern observed in A. latronum demonstrated strong differentiated populations in the Sichuan and Yunnan regions' (Sakka et al. 2010). In the present study, the results of principal component analyses (Figures 2 and 3) showed that the specimens of $A$. latronum (obtained from $18 \mathrm{sam}$ pling areas in southwestern China) cluster into two distinct geographic groups: A. latronum lijiangensis subsp. nov. which includes the specimens from Weixi, Lijiang, and Binchuan areas of Yunnan Province and A. latronum latronum which includes the specimens from Sichuan (Markam, Baoxing, Yajiang, Luhuo, Baiyu, Batang, Danba, Daocheng, Kangding, and Muli areas), southeastern Tibet (Mangkang, Zuogong, and Bomi areas), and northwestern Yunnan (including Deqin and Xiaozhongdian areas) (Figure 4). The multiple comparisons of all 15 cranial variables also indicate significant difference between

Table 6 Measurements $(\mathrm{mm})$ of external and skull variable measurements $(\mathrm{mm})$ of subspecies of Apodemus latronum

\begin{tabular}{|c|c|c|}
\hline \multirow[t]{2}{*}{ Variables } & \multicolumn{2}{|c|}{ Subspecies } \\
\hline & A. latronum latronum & A. latronum lijiangensis \\
\hline $\mathrm{HB}(n=139)$ & $102.72 \pm 7.72(85.00 \sim 118.00)$ & $90.62 \pm 8.44(74.00 \sim 106.00)$ \\
\hline $\operatorname{TL}(n=136)$ & $108.55 \pm 12.32(90.00 \sim 195.00)$ & $94.12 \pm 7.45(78.00 \sim 115.00)$ \\
\hline $\mathrm{HFL}(n=139)$ & $24.30 \pm 1.16(21.00 \sim 26.90)$ & $23.25 \pm 1.40(21.00 \sim 28.00)$ \\
\hline $\mathrm{EL}(n=139)$ & $20.33 \pm 1.24(18.00 \sim 23.00)$ & $19.51 \pm 1.02(18.00 \sim 22.00)$ \\
\hline $\mathrm{GLS}(n=141)$ & $28.82 \pm 0.72(27.26 \sim 30.67)$ & $26.56 \pm 0.90(24.51 \sim 28.08)$ \\
\hline $\mathrm{CBL}(n=141)$ & $25.92 \pm 0.77(24.13 \sim 27.90)$ & $23.79 \pm 0.92(21.65 \sim 25.30)$ \\
\hline $\mathrm{BL}(n=141)$ & $23.86 \pm 0.79(22.15 \sim 25.67)$ & $21.80 \pm 0.91(19.52 \sim 23.33)$ \\
\hline ONL $(n=141)$ & $28.18 \pm 0.76(26.30 \sim 30.52)$ & $26.06 \pm 0.89(24.31 \sim 27.71)$ \\
\hline $\mathrm{PL}(n=141)$ & $14.44 \pm 0.45(13.42 \sim 15.74)$ & $13.27 \pm 0.51(12.31 \sim 14.30)$ \\
\hline $\mathrm{DL}(n=141)$ & $7.64 \pm 0.30(7.01 \sim 8.52)$ & $6.83 \pm 0.33(5.99 \sim 7.39)$ \\
\hline $\operatorname{UTR}(n=141)$ & $13.85 \pm 0.33(13.20 \sim 14.71)$ & $12.73 \pm 0.47(11.82 \sim 13.52)$ \\
\hline $\operatorname{BAM}(n=141)$ & $5.95 \pm 0.19(5.54 \sim 6.37)$ & $5.62 \pm 0.19(4.99 \sim 5.90)$ \\
\hline $\operatorname{BZP}(n=141)$ & $2.96 \pm 0.17(2.60 \sim 3.32)$ & $2.63 \pm 0.21(1.85 \sim 3.13)$ \\
\hline $\mathrm{BOO}(n=141)$ & $6.42 \pm 0.23(5.68 \sim 6.83)$ & $6.07 \pm 0.14(5.69 \sim 6.36)$ \\
\hline $\mathrm{ZW}(n=141)$ & $13.78 \pm 0.39(12.72 \sim 14.63)$ & $12.96 \pm 0.40(11.96 \sim 13.60)$ \\
\hline $\mathrm{IB}(n=141)$ & $4.51 \pm 0.15(4.16 \sim 4.90)$ & $4.35 \pm 0.14(4.01 \sim 4.68)$ \\
\hline $\mathrm{BB}(n=141)$ & $12.49 \pm 0.26(11.96 \sim 13.33)$ & $12.13 \pm 0.30(11.26 \sim 12.61)$ \\
\hline $\operatorname{LLD}(n=141)$ & $3.97 \pm 0.23(3.43 \sim 4.51)$ & $3.76 \pm 0.23(3.12 \sim 4.13)$ \\
\hline $\operatorname{LTR}(n=141)$ & $11.57 \pm 0.34(10.74 \sim 12.43)$ & $10.74 \pm 0.48(9.44 \sim 11.74)$ \\
\hline
\end{tabular}

The variable codes are given in the text and in Figure 1. The values are in mean \pm std. dev. with the range given in parentheses. $\mathrm{HB}$, head and body length; $\mathrm{TL}$, tail length; HFL, hind foot length; EL, ear length. 
Table 7 Measurements $(\mathrm{mm})$ of external and skull of type specimens of Apodemus latronum lijiangensis subsp. nov.

\begin{tabular}{|c|c|c|}
\hline & \multicolumn{2}{|c|}{ Specimen } \\
\hline & Holotype & Paratype \\
\hline Sex & Male & Female \\
\hline $\mathrm{HB}$ & 103 & 102 \\
\hline $\mathrm{TL}$ & 97 & 100 \\
\hline $\mathrm{HFL}$ & 25 & 23 \\
\hline $\mathrm{EL}$ & 20 & 20 \\
\hline GLS & 27.62 & 28.04 \\
\hline CBL & 24.83 & 24.81 \\
\hline$B \mathrm{~L}$ & 22.57 & 22.93 \\
\hline ONL & 27.21 & 27.71 \\
\hline$P L$ & 13.74 & 13.51 \\
\hline $\mathrm{DL}$ & 7.35 & 7.00 \\
\hline UTR & 13.36 & 13.07 \\
\hline BAM & 5.83 & 5.64 \\
\hline BZP & 2.68 & 2.79 \\
\hline $\mathrm{BOO}$ & 6.29 & 6.08 \\
\hline ZW & 13.34 & 13.39 \\
\hline IB & 4.32 & 4.41 \\
\hline BB & 12.36 & 12.23 \\
\hline LLD & 3.98 & 3.91 \\
\hline LTR & 11.36 & 10.46 \\
\hline
\end{tabular}

The variable codes are given in the text and in Figure 1. HB, head and body length; TL, tail length; HFL, hind foot length; EL, ear length.
A. latronum latronum and A. latronum lijiangensis (Table 4). The results of our analyses indicate that aside from the difference in pelage characteristics, apparent geographic variations also exist in cranial morphology.

The results of the $\mathrm{CD}$ analyses indicate that four CDs exceeded 1.28 between A. latronum lijiangensis subsp. nov. and $A$. latronum latronum among these 15 cranial measurements (Table 5). According to the results of Mayr (1969), the CD on subspecific differentiation should be equal to or larger than 1.28 (Mayr 1969); thus, we accept that $A$. latronum lijiangensis subsp. nov. and $A$. latronum latronum should be two valid subspecies within A. latronum. Furthermore, pelage comparison between A. latronum lijiangensis subsp. nov. and A. latronum latronum also sustains their valid subspecies status (Figure 5). Most interestingly thought is that the geographic distribution of the specimens examined in this study (Figure 4) indicates that the A. latronum lijiangensis subsp. nov. and A. latronum latronum are allopatric populations. Given this finding, we strongly suggest that $A$. latronum lijiangensis subsp. nov. should be considered as a valid subspecies of A. latronum.

The locality of the specimens examined in the study nearly covers the distribution areas of $A$. latronum (Figure 4). In terms of biogeography, this area is often ringed by high mountains and deep gorges as a result of the collision of the Indian and Eurasian plates. This area is thought to have the highest species diversity

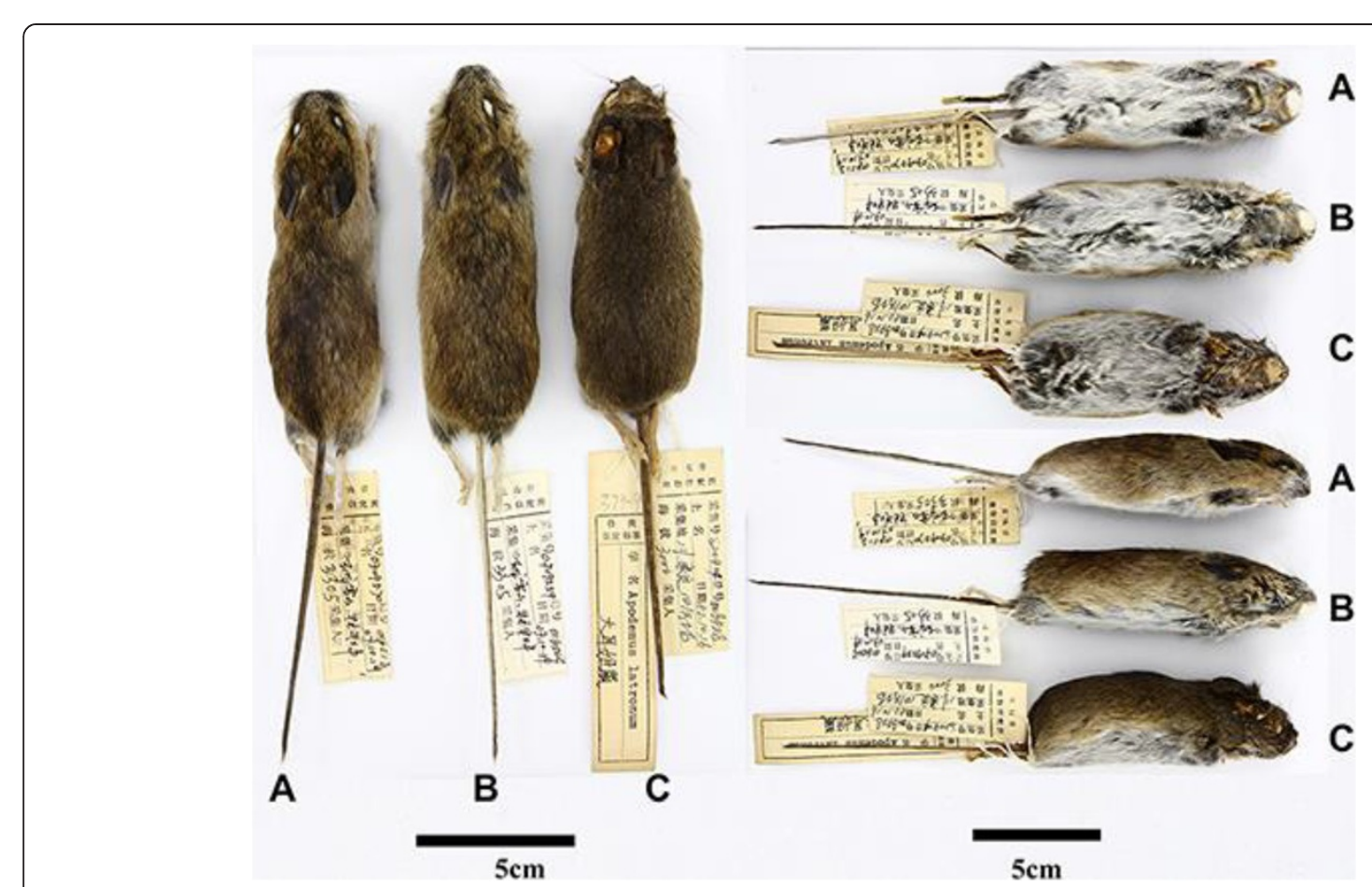

Figure 5 Representative pictures of $\boldsymbol{A}$. latronum latronum and A. latronum lijiangensis. Dorsal (upper left), ventral (upper right), and lateral (lower left). (A) A. latronum lijiangensis (Holotype). (B) A. latronum lijiangensis (paratype). (C) A. latronum latronum (topotype). 
not only in China (Chen 2002) but also in the world (Myers et al. 2000). For endemic species in southwestern China, such as A. latronum, it is certainly plausible that the complicated and varied environments have promoted intra-specific geographic variation, and potentially, that the high mountains and deep gorges act as the main geographic barriers to insulate different geographic populations and influence their gene flow. Though an interesting possibility, any potential connection between the genetic makeup of varying subspecies and their biographic conditions is far outside the realm of a morphometric analysis such as this one. All the same, more studies, especially molecular data analysis, should be performed to reveal the phylogenies of different geographic populations and to probe into the relationships between subspecies differentiation of $A$. latronum and geographical evolution in these areas. Such a case study may strengthen other works on trying to elucidate the actual biogeography of the Yunnan Plateau and its surrounding areas.

\section{Conclusion}

In closing, there was one intriguing finding that bears some exploration. The mean values of the 15 measured skull variables (Table 6) show that on average, the variables of $A$. latronum latronum are larger than those of $A$. latronum lijiangensis subsp. nov., suggesting that $A$. latronum living in lower latitudes have smaller skulls compared to those who inhabit higher latitudes, a supposition fitting Bergmann's rule (Bergmann 1847). However, an entirely different Apodemus species, A. chevrieri, displays an entirely converse size that Bergmann's rule would predict (Li et al. 2008). Exactly why the subspecies we encountered in this study follow the general understanding we have of species at altitude but another species of Apodemus show a contradictory image of skull variable size is a fascinating question. Perhaps further genetic and ecological studies on $A$. latronum as well as its subspecies and other Apodemus species may offer some future insights.

\section{Key to the subspecies of $A$. latronum}

1. General dorsal brown, mixed with black more or less; the muzzle mainly grayish; GLS 26.56 (24.51 28.08 mm), UTR $12.73(11.82 \sim 13.52 \mathrm{~mm})$

\section{- - - - - - - - - - - A. latronum}

lijiangensis subsp. nov.

2. General dorsal ochraceous or ochraceous buff, mixed with black more or less; the muzzle mainly ochraceous but slightly grayer; GLS 28.82
(27.26 30.67 mm), UTR 13.85 (13.20 14.71 mm)

A. latronum latronum

\section{Appendix}

A. latronum lijiangensis, $N=61$

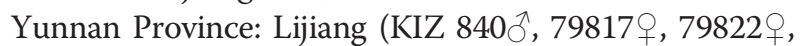

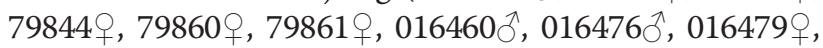

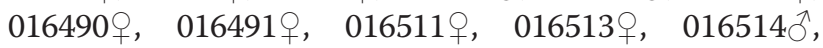

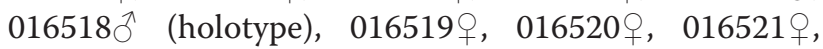
016525우, 016527우, 016528싱 016530우, 016532우,

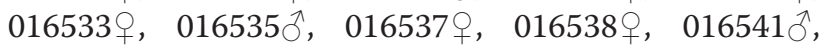

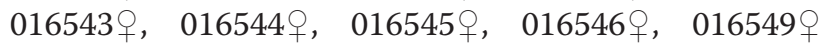

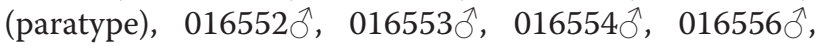

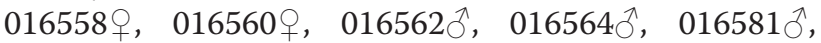
016582 우 $\quad 016584 ㅇ, 016585 ㅇ, 016596 \hat{\jmath}, 016831$, 016832 ㅇ, 016833우); Weixi (KIZ 1115 11116 ㅇ, 810557우, 810558아, 810560우, 810575우, 810576우, 810596우, 810598 ㅇ, 810617우); Binchuan (KIZ 810672ð, 810675).

A. latronum latronum, $N=81$

Yunnan Province: Xiaozhongdian (KIZ 810018 ${ }^{\AA}$,

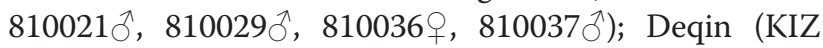

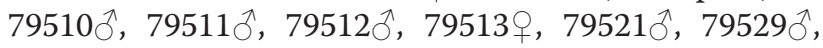

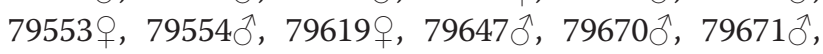
79685 ㅇ, $79686 \hat{\jmath}, 79696 \hat{\jmath}, 79708 \hat{\jmath}, 79713$ ㅇ, $79738 \hat{\jmath}$,

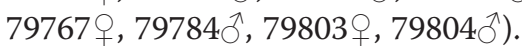

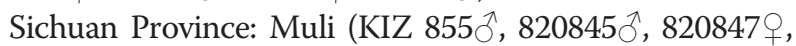
820879 ); (SAF 003). (IOZ 17063ð); Daocheng (KIZ

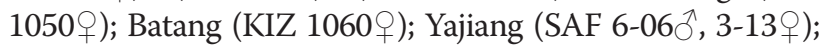
Baoxing (SAF JJSB209, JJSB189ð); Markam (IOZ

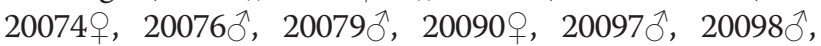

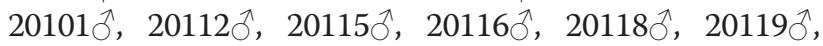
$20121+20136$, 20161 9,20165 , 20167ㅇ, 20166ㅇ, $20169+$, 20170 $q, 20172$, $20174 q$, 20175ㅇ); Baiyu (SAF

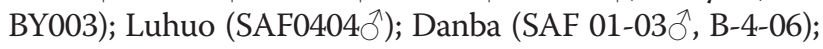
Kangding (KIZ 820404우, no skull).

Xizang Province: Mangkang (KIZ 1074우, 1083 $\left.{ }^{\Uparrow}\right)$; (IOZ

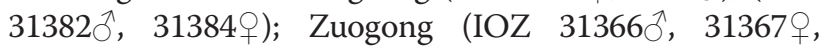

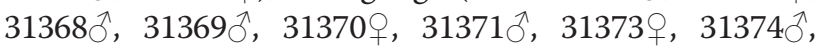
31375ठ̄); Bomi (IOZ 27047ठ̋).

\section{Competing interests}

The authors declare that they have no competing interests.

\section{Authors' contribution}

$S L$ carried out the studies; participated in the design of the study, data collection, and analysis; and drafted the manuscript. SYL participated in data collection and helped draft the manuscript. Both authors read and approved the final manuscript.

\section{Acknowledgements}

This work is conducted at Kunming Institute of Zoology, Chinese Academy of Sciences. Special thanks to Andrew Willden of the Kunming Institute of Zoology for assistance with the manuscript. This study was supported by the National Natural Science Foundation of China (30970332). 


\section{Author details}

'Kunming Natural History Museum of Zoology, Kunming Institute of Zoology, Chinese Academy of Sciences, 32 Jiaochang Donglu, Kunming, Yunnan 650223, China. ${ }^{2}$ State Key Laboratory of Genetic Resources and Evolution, Kunming Institute of Zoology, Chinese Academy of Sciences, Kunming, Yunnan 650223, China. ${ }^{3}$ Sichuan Academy of Forestry, Chengdu, Sichuan 610066, China.

Received: 27 November 2013 Accepted: 18 April 2014

Published online: 03 July 2014

\section{References}

Allen GM (1940) The mammals of China and Mongolia. In: Granger W (ed) Natural History of Central Asia. Central Asiatic Expeditions of the American Museum of Natural History, New York

Bergmann C (1847) Über die Verhältnisse der Wärmeökonomie der ThierezuihrerGrösse. Göttinger Studien 3(1):595-708

Chen XC (ed) (2002) Three Parallel Rivers, National Park. Yunnan Fine Art, Kunming Corbet GB (1978) The mammals of the Palaearctic Region: a systematic review. Cornell University Press, London

Corbet GB, Hill JE (1992) The mammals of the Indomalayan Region: a systematic review. Oxford University Press, Oxford

Ellerman JR (1941) The families and genera of living rodents. Oxford University Press, Oxford

Ellerman JR, Morrison-Scott TCS (1950) Checklist of Palaearctic and Indian mammals 1758 to 1946. British Museum (Natural History), London

Feng ZJ, Cai GQ, Zheng CL (1986) The mammals of Xizang. The comprehensive scientific expedition to the Qinghai-Xizang Plateau. Science, Academia Sinica, Beijing (in Chinese)

Huang WJ, Chen YX, Wen YX (1995) China rodent. Fudan University Publishing House, Shanghai

Li S, Wang YX, Jiang XL, Yang JX (2008) Geographic variation of Chevrier's field mouse (Apodemus chevrieri) (Milne-Edwards, 1868) (Muridae: Murinae) from Southwestern China based on cranial morphometric variables. Zool Stud 47(4):393-401

Lu HQ, Li YC, Zhang XD (1987) Age determination, age structure and population dynamics of striped hamster. Acta Theriologica Sinica 7:35-45

Mayr E (1969) Principles of systematic zoology. McGraw-Hill Book Company, New York

Musser GG, Carleton MD (1993) Family Muridae. In: Wilson DE, Reeder DM (eds) Mammal species of the world: taxonomic and geographic reference, 2nd edn. Smithsonian Institution Press, Washington

Musser GG, Carleton MD (2005) Family Muridae. In: Wilson DE, Reeder DM (eds) Mammal species of the world: taxonomic and geographic reference, 3rd edn. The Johns Hopkins University Press, Baltimore

Musser GG, Brothers EM, Carleton MD, Hutterer R (1996) Taxonomy and distributional records of oriental and European Apodemus, with a review of the Apodemus-Sylvaemus problem. Bonner Zoologische Beitrage 46:143-190

Myers $N$, Mittermeier RA, Mittermeier CG, Fonseca GABDA, Kent J (2000) Biodiversity hotspots for conservation priorities. Nature 403:853-858

Osgood WH (1932) Mammals of the Kelley-Roosevelts and Delacour Asiatic expeditions. Field Museum of Natural History, Zoological Series 18:193-339

Sakka H, Quéré JP, Kartavtseva I, Pavlenko M, Chelomina G, Atopkin D, Bogdanov A, Michaux J (2010) Comparative phylogeography of four Apodemus species (Mammalia: Rodentia) in the Asian Far East: evidence of Quaternary climatic changes in their genetic structure. Biological Journal of Linnaeus Society 100:797-821

Suzuki H, Sato JJ, Tsuchiya K, Luo J, Zhang YP, Wang YX, Jiang XL (2003) Molecular phylogeny of wood mice (Apodemus, Muridae) in East Asia. Biol J Linn Soc 80:469-481

Thomas O (1911) Mammals collected in the provinces of Kan-su and Sze-chwan, western China, by Mr. Malcolm Anderson, for the Duke of
Bedford's exploration of Eastern Asia. Abstr of the Proc Zool Soc Lond 100:49

Wang YX (2003) A complete checklist of mammal species and subspecies in China, a taxonomic and geographic reference. China Forestry Publishing House, Beijing

Zimmermann K (1962) Die Untergattungen der Gattung Apodemus. Bonner Zoologische Beiträge 13:198-208

doi:10.1186/s40555-014-0023-5

Cite this article as: Li and Liu: Geographic variation of the large-eared field mouse (Apodemus latronum Thomas, 1911) (Rodentia: Muridae) with one new subspecies description verified via cranial morphometric variables and pelage characteristics. Zoological Studies 2014 53:23.

\section{Submit your manuscript to a SpringerOpen ${ }^{\circ}$ journal and benefit from:}

- Convenient online submission

- Rigorous peer review

- Immediate publication on acceptance

- Open access: articles freely available online

- High visibility within the field

- Retaining the copyright to your article

Submit your next manuscript at $\gg$ springeropen.com 